UDK 378.14:316.723

DOI: $10.17721 / 2415-881 x .2019 .82 .8-17$

\title{
Mykola Ozhevan
}

Doctor of Philosophical Sciences, Professor, Honored Worker of Science and Technology of Ukraine, Chief researcher, National Institute for Strategic Studies (Kyiv, Ukraine) https://orcid.org/0000-0002-5729-7947

e-mail: ozhevan@niss.gov.ua

\section{INTEGRITY IN SOCIAL HUMANITARIAN SCIENCES AS A PHILOSOPHICAL\&METHODOLOGICAL PROBLEM}

\begin{abstract}
The main determinants of scientific integrity are considered in the article: moral and ethical; religious and ideological; philosophical and methodological; political and legal; social with criminogenic inclusive; technical and technological; advertising and marketing.

The main attention is drawn to the crisis in the social and humanitarian sciences which in Ukrainian conditions can be explained in the broad sense by the legacy of the Soviet past, when the social humanitarian sciences (the social sciences and the humanities in western understanding) were predominantly promoted with ideological goals. The quasi scientific practice that drove in Soviet times was the practice of artificial scientification of various political doctrines and ideologies based on the «one correct doctrine»—Marxism-Leninism («scientific communism»; «scientific atheism», etc.). Competing doctrines declared unscientific.

At the more late time, the manifestations of scientific malpractice are commercial facilitated researches. To this over-commercialization and over-politicization factors we must add the relativism of the postmodern worldview with its dubious «post-truth» ideal.

The article suggests various ways and methods solving the problem of strengthening the scientific integrity: philosophical; moral\&ethical; political\&legal; corporate-administrative.

Key words: scientific integrity; corporatism in science; corporate ethics; postmodernism
\end{abstract}




\section{Ожеван Микола Андрійович}

Доктор філософських наук. професор, Заслужений діяч науки і техніки України, головний науковий співробітник, Національний інститут стратегічних досліджень (м. Київ, Україна)

https://orcid.org/0000-0002-5729-7947

e-mail: ozhevan@niss.gov.ua

\section{ДОБРОЧЕСНІСТЬ У СОЦІОГУМАНІТАРНИХ НАУКАХ ЯК ФІЛОСОФСЬКО- МЕТОДОЛОГІЧНА ПРОБЛЕМА}

\section{Резюме}

У статті здійснена спроба фокусування основних детермінант наукової доброчесності (моральнісно-етичних; релігійних та ідеологічних; філософсько-методологічних; методикометодологічних; політико-правових; соціальних включно 3 криміногенними; технікотехнологічних; рекламно-маркетингових) на сферу соціогуманітарних наук. Основну увагу привернено до кризи соціогуманітарних наук у нинішніх українських умовах, яку значною мірою можна пояснити спадщиною радянського минулого, коли на соціогуманітарні науки були покладені переважно ідеолого-пропагандистські, квазірелігійні функції. Водночас, за радянських часів правилом «гарного тону» був штучний сцієнтизм у позитивістському сенсі, наслідком якого стало «онауковлення» різноманітних політичних вчень та ідеологій, вибудуваних на грунті «єдино правильного вчення» — марксизму-ленінізму («науковий комунізм»; «науковий атеїзм» тощо). У пострадянський період ця сумнівна спадщина «тотальної науковості» обертається чисельними проявами наукової не доброчесності, до яких додаються новітні чинники надмірної комерціалізації та політизації науки. Свій негативний внесок вносить і постмодерний релятивізм з його сумнівним ідеалом «постправди», коли віра передує об'єктивному знанню, а результати наукового пошуку зазвичай підлаштовують під наперед задані догми. У статті проводяться чіткі демаркації між філософсько-світоглядним, моральнісно-етичним та юридичним й корпоративно-адміністративним аспектами розв'язання даної складної проблеми.

Ключові слова: наукова доброчесність; корпоративізм в науці; корпоративна етика; постмодернізм

\section{Bcmyn}

Ідеал Науки в наш час дедалі більше профанується, зазнаючи дедалі серйозніших випробувань під тиском комерціалізації, а «людина науки» (науковець, вчений, дослідник) втрачає сакральний моральнісно-етичний ореол і навіть соціальний статус і престиж, перетворюючись на людину, яка більш-менш успішно продукує знання й практичні вміння, навички, «компетентності».

Дедалі більших темпів набувають медіатизація, мілітаризація та політизація наукових досліджень, за умов яких спрацьовує ефект зворотного зв'язку, який аж ніяк не сприяє доброчесності наукових пошуків. Оскільки замовники наукових досліджень безпосередньо або опосеред- 
ковано диктують волю дослідникам, останнім дедалі важче чинити спротив спокусам «вільного ринку» й пересічного заробітчанства, дотримуючись ідеалів неупередженості та об'єктивності наукового пошуку.

Усе зазначене передусім стосується соціогуманітарних наук, статус яких в українських реаліях, до того ж, належним чином не конституювався. Якщо в західних умовах «гуманітарні дослідження» (англ. «humanities») зазвичай віднесені до різновиду «мистецтв» (англ. «arts»), то у вітчизняних умовах їх фактично прирівнюють до природничих та математичних наук, що породжує чимало дрібних і великих непорозумінь.

Водночас, апріорі зрозуміло, що без неупередженого наукового пошуку із дотриманням відповідних норм та правил кодексів доброчесності втрачають сенс як сам цей пошук, так і його результати. А головне - втрачається довіра соціуму і держави до науки як винятково важливого соціального інституту зі своїм унікальними етосом, етикою та деонтологією.

\section{Методи дослідження}

Використано філософсько-методологічний та історико-політологічний методи, а також принципи та методи критично-конструктивного, порівняльного аналізу.

Критично проаналізовані підходи авторів чи цілих груп авторів, які пропонують більшменш універсальні чи більш-менш унікальні підходи до розуміння складного феномену «наукової доброчесності», його різноманітні визначення. Виявлено, що усі ці методи та підходи у явно вираженій або завуальованій формі апелюють до концепту корпоративної етики.

\section{Результати}

Корпоративний підхід означає з моральнісно-етичної та правової точок зору пошук певної точки рівноваги між індивідуальними та груповими правами й обов'язками, а на практиці означає, що індивід, набувши корпоративного статусу (інкорпорувавшись), має багато чим пожертвувати на користь корпорації, хоча й корпорація бере на себе зобов'язання захищати індивіда та його близьких.

У вищезазначеному корпоративному сенсі інтегральність науки як інституції, корпорації (англ. «integrity»), означає їі моральнісно-етичну «цілісність», тобто формально чи неформально скріплений намір науковців як учасників великої соціальної групи (інституції, копорації) дотримуватися умов соціального контракту, відповідно до якого індивіди в обмін на користування правами беруть нас себе зобов'язання щодо дотримання певних правил, норм, нормативів тощо із відповідними заохочувальними або каральними санкціями.

Отже, немає жодних сумнівів, що термін «доброчесність» має фігурувати на почесних ролях у різноманітних «Кодексах честі», які стосуються звичаєвого права. У Польщі, наприклад, існують рекомендаційно-дидактичні матеріали: «Пристойна поведінка в науці» (польськ. «Dobre obyczaje w nauce») [1].

Такі ж самі або подібні деонтологічні настановлення існують в кожній цивілізованій країні, хоча донедавна вони були відсутні в СРСР та пострадянських країнах з Україною включно, що відбувалося тільки тому, що держава підмінювала собою громадські інституції й вважала, що «Морального кодексу будівника комунізму» цілковито достатньо для регулювання поведінки усіх і вся, оскільки усі інші моральні кодекси мали бути похідними від цього базового «комуністичного» кодексу.

Лікарі в СРСР, приміром, отримуючи лікарський диплом, давали не «Клятву Гіппократа», як це робилося у західному світі, а «Присягу радянського лікаря» й т. п. Не дивно, що за таких умов цілі галузі медичної науки у певні періоди радянської історії криміналізувалися на догоду каральним спецслужбам. Прикладом може бути хоча б радянська «каральна психіатрія». Один з радянських провідних психіатрів, академік О. В. Снєжневський (академік-секретар Відділення клінічної медицини АМН СРСР у 1966-1976 рр. ) навіть придумав і обгрунтував існування спеціального психічного захворювання - «мляво-плинної шизофренії», яке діагностували недоброчесні лікарі щодо деяких радянських дисидентів, одним з яких був генерал П. Г. Григоренко. 
Разом 3 тим, незалежна психіатрична експертиза, яку у 1971 році провів С. Ф. Глузман, не дозволила подальше утримання П. Г. Григоренка в психіатричній установі. У 1972 році Семен Глузман був засуджений головно за вказану незалежну експертизу на сім років концтаборів, додатково йому дали три роки заслання.

«Кодекс етики в науці», ухвалений у 2012 році Польською академією наук, заснований на кращих світових та європейських взірцях, вимагає від науковців слідування наступним моральнісно-етичним принципам:

1. Старанності (англ. «Diligence»; рос. «Усердие»).

2. Сумлінності (англ. «Trustworthiness»).

3. Об’єктивності (англ. «Objectivity»).

4. Неупередженості (англ. «Impartiality»).

5. Опірності (англ. «Resistance») стосовно будь-яких спроб зовнішнього впливу на проведення даного дослідження.

6. Відкритості (англ. «Openness»).

7. Прозорості (англ. «Transparency»).

8. Відповідальності (англ. «Responsibility»).

9. Достовірності (англ. «Reliability»).

10. Турботливості (англ. «Concern»).

11. Мужності (англ. «Courage») [2].

Серйозним викликом $\epsilon$ конверсія моральнісно-етичних правил «доброчесності» у «симетричні» юридичні поняття й термінологію. Оскільки цей процес із суто практичної точки зору є досить проблематичним, то у більшості країн світу законодавці намагалися уникати подібних трансформацій, тобто перетворення етичних кодексів на кодекси юридичні. Хоча існує й чимало винятків.

У США, зокрема, існують різного рівня юридичні акти, які стосуються «науководослідницької доброчесності» (англ. «scientific integrity»; «research integrity»), особливо у тій частині, яка стосується дослідження суспільно-важливих проблем, пов'язаних з охороною здоров'я, захистом довкілля тощо. На сторожі дотримання цих законів активно діють відповідні державні контрольні інстанції, а порушників запропонованих державою норм і правил очікують строгі каральні санкції.

На жаль, поняттям «доброчесності» не оперує український закон «Про наукову і науковотехнічну діяльність» (принаймні, не оперує безпосередньо) [3].

Загалом, слід зауважити, що англомовні терміни «асademic/scientific honesty» та «academic integrity» (антонімами тут є «academic/scientific dishonesty»; «academic disintegrity»; «academic misconduct») далеко не завжди відтворюються українськими авторами в належних контекстах. Ігнорується зокрема той факт, що на Заході подібна термінологія віддавна використовується у контексті більш-менш послідовної політики «нульової толерантності» щодо усіх без винятків порушників кодексів наукової честі (англ. «zero tolerance honor code»).

Натомість в українських умовах звинувачення в недоброчесності (зокрема у частині дисертаційного плагіату) зазвичай стосуються високопосадовців та членів їхніх родин, популярних журналістів-розслідувачів, тобто використовуються з метою булінгу (цькування).

До того ж, англійське «disintegrity», яке означає вочевидь «дезінтеграцію» як порушення цілісності дійсно відповідає тривожним тенденціям до надто вузької спеціалізації в науці та освіті, що призводить до їхнього відриву від філософії, релігії та гуманітарної культури в цілому, що з необхідністю сприяє шахраюванню, підробці наукових результатів тощо.

Достатньо переглянути ті «правила доброчесності», які пропонують західні вузи й наукові лабораторії та ті державні установи, які контролюють їхню діяльність, щоб зрозуміти, що український Закон «Про наукову і науково-технічну діяльність» багатьма 3 них знехтував. Йдеться зокрема про «саботаж» (англ. «sabotage»), під яким слід розуміти «дії, скеровані на перешкоджання іншим учасникам процесу якісно виконати свою роботу». Діапазон таких шкідницьких 
дій, як вказує польський Закон «Про вищу школу й науку» від 2018 року, є досить широким, починаючи із виривання сторінок бібліотечних підручників й закінчуючи втручанням в хід наукових експериментів тощо [4].

У будь-якому разі, справи з моральнісним кліматом в сфері наукових досліджень $є$ досить тривожними не тільки в Україні, але і в усьому світі. У США, наприклад, свого часу чималого резонансу набув скандал «Справа Балтимора», головним фігурантом якого став Девід Балтимор (David Baltimore), нобелівський лауреат 1975 року в сфері медичної імунології, уся провина якого полягала лише в тому, що він тривалий честь обстоював доброчесність Терези ІмашіKapi (Thereza Imanishi-Kari), авторки статті, наукові дані якої поставила під сумнів урядова установа США, — Комісія з науково-дослідницької доброчесності (англ. «The Office of Research Integrity-ORI»). Зрештою, Комісія виявилася правою, а нобелівський лауреат неправим чим значною мірою «підмочив» свою репутацію [5].

На чистоту досліджень накладає нині істотний відбиток той факт, що наукові результати творять не талановиті одинаки, а великі колективи. За подібних умов авторство і відповідальність за якість отриманих результатів анонімізуються, втрачають адресата. Сам науковий результат набуває за сучасних умов ознак товару, який принципово нічим не вирізняється від усіх інших товарів, а наукове дослідження перетворюється на результат реалізації контракту між науковою лабораторією та іiі власниками, з одного боку, й фірмою (корпорацією), яка замовила дане дослідження, з іншого. Водночас, окрім негативів, даний феномені узалежнення дослідника від замовника позначений, окрім негативів, певними позитивами. Зокрема, йдеться про комерційну або політичну зацікавленість в результатах дослідження, що посилює контроль за коректним витрачанням фінансів, вкладених у майбутні результати.

На сайті вже згаданої американської установи,-Комісії з науково-дослідницької доброчесності (ORI), підпорядкованої Міністерству охорони здоров'я та соціальних служб США (існує від 1992 р. ), можна наочно відстежити зростаючу активність цієї установи [6]. Подібний контроль науково-дослідницької доброчесності / недоброчесності (англ. «research misconduct») було започатковано у США у 1981 році, коли відбулися перші конгресові слухання, присвячені цій проблемі під головуванням майбутнього віце-президента Альберта Гора. В процесі цих слухань було виявлено неблагополуччя, яке стосувалося станом на 1980 рік чотирьох американських дослідницьких центрів. За період 1974-1981 рр. було виявлено ще 12-ть подібних «кейсів». У подальшому їхнє число тільки зростало [6].

Контролювати наукові процеси та результати досліджень стає дедалі важче передусім із-за лавиноподібного зростання числа наукових видань. Коли 1665 році з'явилися два перших наукових часописи - «Le Journal des Sçavans» («Журнал вчених») у Франції та «Philosophical Transactions» («Філософські бесіди») як орган Королівського Товариства («Royal Society») в Англії йшлося про десятки публікацій. Станом на 2009 рік таких наукових статей уже акумулювалося до позначки в 50 млн. [7]. У подальшому число подібних публікацій зростало темпами три відсотки річно, тобто станом на 2019 рік їх уже було близько 70 млн. Станом на 2016 рік у світі публікувалося 10000 наукових журналів, із яких половина були індексованими у науковометричній базі Scopus [8].

Аж до середини XX ст. діяльність наукових видань саморегулювалася й й за подібних умов не потрібні були навіть зовнішні наукові рецензії. Проте, нині процес істотно ускладнився. Окрім рецензій, потрібна ще й каталогізація публікацій в різноманітних «індексах цитування». Самі наукові часописи, залежно від цитованості розміщених в них матеріалів отримують «фактор впливовості» (англ. «іmpact factor IF»).)

За даними ЮНЕСКО, впродовж шести років (між 2008 й 2014 роками) число наукових статей, індексованих у The Science Citation Index of Thomson Reuters «Web of Science» зросло на 23\% (від 1, 03 млн. до 1, 27 млн. ). Ці дані свідчать про те, що США поступово втрачають свої позиції найбільшого світового наукового публікатора. Зокрема, якщо у 2008 році їм належало 28,1\% усіх світових наукових публікацій, то у 2014 році-тільки-25,3\%. Натомість за цей 
самий період КНР здійснила стрімке сходження від 9.9\% до 20.2\% світових наукових публікацій. Третина (34\%) усіх наукових публікацій припадала у 2014 році на долю країн ЄС. На цьому тлі досить скромною була дольова участь арабських країн (2,4\%); РФ (2,3\%); Ірану (2\%) [9].

Порівняно новим явищем у сфері наукових публікацій стало «відкликання» (англ. «retraction») уже опублікованих наукових матеріалів у зв'язки з тим, що у подальшому як самі автори, так і керівники відповідних науково-дослідницьких установ, зовнішні критики тощо знаходять у цих публікаціях різноманітні недоліки з проявами наукової недоброчесності включно.

Тут неважко віднайти аналогії з дуже популярним відкликанням з ринку індустріальних продуктів, що перетворилося навіть на форму реклами, оскільки побічно засвідчує прагнення виробників до досконалості. Тому не дивно, що часописи з високим «impact factor» відкликають публікації набагато частіше, аніж ті, що мають порівняно низький «impact factor». Тривожним однак $\epsilon$ той факт, що впродовж останнього десятиліття (2008-2018 рр. ) число «відкликаних» публікацій зросло вдесятеро. У більшості випадків йдеться про «фейкові» рецензії, плагіат, підтасування даних, інші форми шахраювання [10].

Як зазначає Матей Грабський, найбільш спокусливими для різних шахраїв $є$ ті галузі науки, де неможливе точне замірювання отриманих результатів. Саме тому «м'які» науки мають чимало шансів перероджуватися на «сміттєві» (англ. «јunk science»; досл. «науковий мотлох») [11].

Щоправда, зустрічаючи в мас-медіа звинувачення в академічній недоброчесності певних наукових установ чи окремих науковців, викладачів тощо, не слід бути надто довірливим, враховуючи той факт, що різні зацікавлені особи або їхні лобісти, яких не влаштовують певні наукові результати, можуть зарахувати їх до «наукового мотлоху». Типовою у цьому плані $\epsilon$ вельми суперечлива й надмірно політизована проблема «глобального потепління». Виробники твердого палива замовляють науковцям результати, які мали би підтверджувати відсутність безпосереднього зв'язку між феноменом «глобального потепління» та викидами в атмосферу двоокису вуглецю.

До речі, саме таку точку зору на глобальне потепління, яка співпадає 3 точкою зору 45-го президента США Дональда Трампа, обстоює, починаючи від 1 квітня 1996 року (тобто за 20-ть років до того як американці виборці віддали на президентських виборах 2016 року перевагу Дональду Трампу), спеціалізований сайт «Сміттєва наука» («Junk Science»), який провадить Стів Міллой (Steve Milloy), оглядач телеканалу Fox News. Заодно від цього оглядача т а його колег перепадає науковцям, які доводять існування «озонових дір», шкідливість «пасивного паління» цигарок тощо [12].

На особливу «увагу пильності» заслуговують «науки в стилі культу карго» (англ. «Cargo cult science»). Походження терміну пов'язане з тим, що антропологи виявили свого часу на островах Меланезії вельми екзотичний «культ карго», походження якого пов'язане з тим, що на цих островах під час Другої Світової війни приземлялися американські вантажні літаки типу «Геркулес». Коли ж війна закінчилася, літаки перестали прилітати, остров'янам більше не перепадали з цим пов'язані матеріальні блага. Відтак вони почали культивувати магічні ритуали, покликані «простимулювати» американські «Геркулеси» до нових вильотів. Відтак, виникла релігія «літакошанувальників» або ж культ «Дарів небесних». У метафоричному сенсі під «культом карго» розуміють формальне застосування тих чи інших наукових чи квазінаукових методологій без розуміння сутності й істинного призначення відповідних процесів [13].

Як підкреслював Ричард Фейнман, виступаючи у 1974 році перед випускниками Каліфорнійського технологічного інституту («CalTech»), у науці теж можуть відбуватися фіктивно-демонстративні процеси, подібні до карго-культу. Цей виступ, який отримав назву «Наука літакошанувальників», увійшов до книги «Ви, звичайно, жартуєте, містер Фейнман». Йдеться про ті квазінаукові процеси, учасники яких імітують науковий метод, не отримуючи від цього жодного корисного результату; головно тому, що, буцімто турбуючись про утвердження істини в останній інстанції, намагаються тимчасом здобути хоча б видимість омріяного результату [14]. 
Карго-культ у фейнманівському розумінні звичайно може стосуватися й «точних» наук. Але ще більшою мірою він притаманний за пострадянських умов соціально-гуманітарним наукам та соціальній практиці, яку вони намагаються «обгрунтовувати». У цьому контексті Михайло Вербицький доречно порівняв з карго-культом спроби побудови в пострадянській Росії соціальних інститутів, які зовні копіювали західні, але виявилися недієвими. Найцікавіше тут полягає в тому, із подібної неефективності і в Росії, і в багатьох інших пострадянських республіках робляться зворотні проекції, тобто на тій підставі, що в Росії (СРСР) не спрацьовують їхні імітаційно-профанаційні, квазі-сакральні копії («літаки не літають») принципи, на яких побудовані західні соціальні інститути, оголошуються фальшивими й навіть шкідницькими [15].

На особливу увагу у плані дотримання норм доброчесності в соціально-гуманітарних науках заслуговує питання плагіату. Латинське «plagiarius» початково стосувалося викрадення дітей, рабів, тобто мало стосунок до явища, яке нині прийнято познбачати як «кіднепінг». Згодом «плагіаторами» почали називати викрадачів (присвоювачів) чужих літературних текстів.

3 методологічної точки зору доцільно розрізняти концептуальний (парадигмальний) та периферійний плагіат. Те, що зазвичай вважають «плагіатом», пропускаючи тексти через спеціалізовані машини типу «Антиплагіат», насправді дуже часто є результатом незумисного порушення правил роботи з джерелами інформації: неточності у цитуванні джерел, надто тісному щодо джерела походження парафразуванні (переказуванні) чужої думки тощо. Плагіат в концептуально-парадигмальному сенсі є набагато серйознішим злом, оскільки є цілковито зумисним, мотивованим бажанням обманути «лоха», викраденням чужої інтелектуальної власності або їі запозиченням без наміру коли-небудь повернути позичене [16-17].

«Делікатною специфікою» вищої школи в епоху інформаційної революції є існування чисельних «фабрик дисертацій» (англ. «paper mills college essays»), де трудяться різні «літературні негри» (англ. «ghostwriters»), послугами яких часто користуються недоброчесні, але матеріально забезпечені, студенти й аспіранти (докторанти).

Разом з тим, поширене у всьому світі з Україною включно явище існування ринків інтелектуальних послуг й «примарного» чи підставного «авторства» не отримало поки що однозначної правової й моральнісної оцінки. 3 одного боку, з цим феноменом пов'язані зазначені вище конгломерати «фабрик дисертацій», яких, за даними британської спеціалізованої агенції з контролю якості вищої освіти (аналог українського НАЗЯВО), тільки в Великобританії нараховується більше сотні [18].

Хоча, подібні «фабрики» буцімто пропонують контент, вільний від плагіату (англ. «plagiarism-free content») насправді ці «фабрики» є типовими колективними плагіаторами, оскільки де-факто практикують викрадення чужої інтелектуальної власності, формально не порушуючи авторського права. Звичайно, плоди сумнівної діяльності подібних «фабрик» не давали б жодного зиску їхніх власникам та «літературним неграм» у них задіяним, якби ця діяльність не отримувала підтримки «нагорі», на рівні недоброякісних захисних рад, вузівських адміністрацій тощо та різних високопосадовців, які самі часто експлуатують «літературних негрів» з метою захисту «vip-дисертацій», написання «епохальних творів», мемуарів тощо.

Різні країни пропонують різні практики боротьби з «еssays mills», хоча наразі майже всі ці практики виявляються неефективними. У США зокрема немає федерального закону, який забороняв би подібну діяльність, хоча такі законні обмеження діють на рівні окремих штатів. Подібна заборона діє також у Новій Зеландії. Проте «еssays mills» завжди можуть знайти обхідні шляхи щодо подібних обмежень та заборон. Наприклад, «Elizabeth Hall Associates», одна 3 найбільших в Великобританії «фабрик наукових паперів», спонукує замовників для перестрахування потенційної юридичної відповідальності за виробництво квазіакадемічних праць підписувати з «фабрикою» зобов'язання (англ. «disclaimer»), у якому йдеться про те, що куплений інтелектуальний продукт вони не будуть представляти у певному вузі (науковій устано- 
ві) як свій власний, а будуть використовувати його виключно як «модельний об'єкт» (англ. «а guidance model only») [19].

Слід зазначити відсутність серйозних філософсько-методологічних розробок з проблем порушення немайнових авторських прав, незахищених чинним законодавством, неосудних або напівосудних з моральнісно-етичної точки зору. У цьому контексті слід зауважити, що в античній та середньовічній філософії й науці (на той час це було одне й те саме) взагалі було відсутнє поняття одноосібного авторства й чимало авторів видавало свої твори, користуючись «розкрученими брендами» Платона, Аристотеля тощо. Лише з початком у XVII ст. сучасної наукової революції утвердилося поняття «автора». I так тривало аж до 20-х рр. XX століття.

До того ж, в різних сферах науки й культури поняття авторства та визначення дольової співучасті в колективному авторстві має свою специфіку. Наприклад чимало медичних журналів взагалі відмовилися від поняття «автор» на користь поняття «співучасник» (англ. «contributor»). 3'явилось також малозрозуміле поняття «почесного авторства» (англ. «honorable authorship»). Ще менш зрозумілим з моральнісно-етичної точки зору є «примарне авторство» (англ. «ghost writer»), коли справжній автор залишається невідомим. Йдеться зокрема про випадки, коли за наполяганням фармацевтичних компаній «авторами» публікацій часто є відомі люди, які не мають жодного відношення до даного дослідження й навіть не давали згоди на використання своїх прізвищ у переліках авторів. Але оскільки їхній науковий та публічний авторитет має для комерційних компаній винятково важливе рекламне значення, то з'являються подібні квазавтори.

На цьому тлі варто зазначити, що звичним явищем не тільки в українській науці, але й науці на всьому просторі СНД є приписування до прізвища справжнього автора (авторів) роботи цілої низки прізвищ авторів, які мають до цієї роботи суто опосередковане адміністративне відношення.

\section{Висновки}

Академічна й наукова доброчесність у їі корпоративному (неокорпоративному) розумінні $є$ тим резервом підняття якості освіти й науки, який не потребує особливих матеріальнофінансових інвестицій, але може за належної уваги до даної проблеми обернутися відчутними позитивними зрушеннями в українській науці та освіті. У будь-якому разі, заради збереження й примноження належної якості освіти й науки Україні, оздоровлення інтелектуального клімату в науці слід вести рішучу боротьбу з й науковою недоброчесністю у всіх іï формах та різновидах, що має перетворитися на один з перспективних напрямів створення в Україні ефективної антикорупційної системи.

Оскільки академічна й наукова) культура є похідними від культури соціуму, то апріорі зрозуміло, що усі соціальні групи у хворому соціумі будуть хворими й дотримання соціального контракту учасниками окремої групи неможливе, якщо на рівні всього українського соціуму не діятиме «Великий Контракт» 3 усіма його моральнісно-етичними та політико-юридичними імперативами й регулятивами.

\section{СПИСОК ЛІТЕРАТУРИ:}

1. Dobre obyczaje w nauce. Zbior zasad i wytycznych, wydanie III, PAN, Warszawa, 2001.

2. The Code of Ethics in Science. The Commission on Ethics in Science. 2012. Annex to Resolution No. 10/2012 of the General Assembly of the Polish Academy of Sciences of 13 December 2012, available at ue. poznan. pl/.../88.\%20The\%20Code\%20of\%20Ethics\%20i (accessed 04 December 2019).

3. Закон України. Про наукову і науково-технічну діяльність. Відомості Верховної Ради (BBP), 2016. № 3, ст. 25, available at: http://zakon. rada. gov. ua/laws/show/848-19 (accessed 04 December 2019). 
4. Prawo o szkolnictwie wyższym i nauce. Ustawa z dnia 20 lipca 2018 r. Dziennik Ustaw Rzeczypospolitej Polskiej. Warszawa, dnia 30 sierpnia 2018 r. Poz. 1668. available at: https://www. gov. pl/web/nauka/konstytucja-dla-nauki-2 (accessed 04 December 2019).

5. Kelves D.J. The Baltimore Case: A Trial of Politics, Science and Character, Norton, New York, 1998.

6. The Office of Research Integrity. available at: https://ori. hhs. gov (accessed 04 December 2019).

7. Jinha, Arif E. (2010). Article 50 million: an estimate of the number of scholarly articles in existence. Learned Publishing. Vol. 23. № 3. July 2010, pp. 258-263.

8. Johnson, Rob. Watkinson, Anthony. Mabe, Michael (2018). The STM Report. An overview of scientific and scholarly publishing. 2018, available at: https://www. stm-assoc. org/2018_10_04_ STM_Report_2018.pdf (accessed 04 December 2019).

9. Facts and figures: publications. The UNESCO Science Report, Towards 2030. available at: https://en. unesco. org/node/252282 (accessed 04 December 2019).

10. Brainard, Jeffrey. You, Jia (2018). What a massive database of retracted papers reveals about science publishing's «death penalty». Science. Oct. 25, 2018, available at: https://www. sciencemag. org/news/2018/10/what-massive-database-retracted-papers-reveals-about-science-publishing-sdeath-penalty (accessed 04 December 2019).

11. Grabski, Maciej W (2009). Uczciwość i wiarygodność nauki. Praktyka. Nauka. 2009. № 2. S. $37-59$.

12. Junk Science, available at: https://junkscience. com (accessed 04 December 2019).

13. Культ карго. Вікіпедія. available at: https://uk. wikipedia. org/wiki (accessed 04 December 2019).

14. Feynman, Richard P. Cargo Cult Science, available at: http://calteches. library. caltech. edu/51/2/CargoCult. pdf (accessed 04 December 2019).

15. Самолетопоклонники. Look at me, available at: http://www. lookatme. ru/flow/obschestvo/ obschestvo/99659-samoletopoklonniki (accessed 04 December 2019).

16. Macdonald, R., Carroll, J. (2006). Plagiarism: A complex issue requiring a holistic Approach. Assessment and Evaluation in Higher Education, 2006. No. 31 (2). P. 233-245.

17. Левин В.И. (2014). Плагиат в российской науке. Alma Mater, № 6, Июнь 2014, С. $111-114$.

18. Stevenson, Seth, Adventures in Cheating. A guide to buying term papers online. Slate, available at: http://www. slate. com/articles/life/shopping/2001/12/adventures_in_cheating. html (accessed 04 December 2019).

19. Yorke, Harry (2017). University students could be fined or handed criminal records for plagiarised essays, new proposals suggest. The Telegraph. 21 February 2017, available at: http://www. telegraph. co. uk/education/2017/02/21/university-students-could-fined-handedcriminal-recordsplagiarised (accessed 04 December 2019).

\section{REFERENCES:}

1. Dobre obyczaje w nauce. Zbior zasad i wytycznych, wydanie III, PAN, Warszawa, 2001.

2. The Code of Ethics in Science (2012). The Commission on Ethics in Science.. Annex to Resolution No. 10/2012 of the General Assembly of the Polish Academy of Sciences of 13 December 2012, available at: ue. poznan. pl/.../88.\%20The\%20Code\%20of\%20Ethics\%20i (accessed 04 December 2019).

3. Zakon Ukrainy. O nauchnoy i nauchno-tekhnicheskoy deyatel'nosti. Zvedeniya Verkhovnoy Rady (VVR), 2016. № 3. st. 25, available at: http://zakon. rada. gov. ua/laws/show/848-19 (accessed 04 December 2019). 
4. Prawo o szkolnictwie wyższym i nauce. Ustawa z dnia 20 lipca 2018 r. Dziennik Ustaw Rzeczypospolitej Polskiej. Warszawa, dnia 30 sierpnia 2018 r. Poz. 1668, available at: https://www. gov. pl/web/nauka/konstytucja-dla-nauki-2 (accessed 04 December 2019).

5. Kelves D.J. (1998).The Baltimore Case: A Trial of Politics, Science and Character, Norton, New York, 2019).

6. The Office of Research Integrity, available at: https://ori. hhs. gov (accessed 04 December

7. Jinha, Arif E. (2010). Article 50 million: an estimate of the number of scholarly articles in existence. Learned Publishing. Vol. 23. № 3. July, Pp. 258-263.

8. Johnson, Rob. Watkinson, Anthony. Mabe, Michael (2018). The STM Report. An overview of scientific and scholarly publishing, available at: https://www. stm-assoc. org/2018_10_04_STM_ Report_2018.pdf (accessed 04 December 2019).

9. Facts and figures: publications. The UNESCO Science Report, Towards 2030, available at: https://en. unesco. org/node/252282 (accessed 04 December 2019).

10. Brainard, Jeffrey. You, Jia. (2018). What a massive database of retracted papers reveals about science publishing's «death penalty». Science. Oct. 25, 2018, available at: https://www. sciencemag. org/news/2018/10/what-massive-database-retracted-papers-reveals-about-science-publishing-sdeath-penalty (accessed 04 December 2019).

11. Grabski, Maciej W. (2009). Uczciwość i wiarygodność nauki. Praktyka. Nauka. 2009. № 2. S. $37-59$.

12. Junk Science, available at: https://junkscience. com (accessed 04 December 2019). 2019).

13. Cult cargo // Wikipedia. available at: https://uk. wikipedia. org/wiki (accessed 04 December

14. Feynman, Richard P. Cargo Cult Science, available at: http://calteches. library. caltech. edu/51/2/CargoCult. pdf (accessed 04 December 2019).

15. Samolotopoklonniki // Look at me, available at: http://www. lookatme. ru/flow/obschestvo/ obschestvo/99659-samoletopoklonniki (accessed 04 December 2019).

16. Macdonald, R., Carroll, J. (2006). Plagiarism: A complex issue requiring a holistic Approach. Assessment and Evaluation in Higher Education, 2006. No. 31 (2). P. 233-245.

17. Levin V.I. (2014). Plagiat v rossiyskoy nauke. Alma Mater. № 6, 2014. S. 111-114.

18. Stevenson, Seth, Adventures in Cheating. A guide to buying term papers online. Slate, available at: http://www. slate. com/articles/life/shopping/2001/12/adventures_in_cheating. html (accessed 04 December 2019).

19. Yorke, Harry (2017). University students could be fined or handed criminal records for plagiarised essays, new proposals suggest. The Telegraph. 21 February 2017, available at: http://www. telegraph. co. uk/education/2017/02/21/university-students-could-fined-handedcriminal-recordsplagiarised (accessed 04 December 2019). 